\title{
RELIGIUSITAS SISWA MADRASAH ALIYAH DAN SEKOLAH MENENGAH ATAS
}

\section{STUDENT'S RELIGIOSITY IN MADRASAH ALIYAH AND SENIOR HIGH SCHOOL}

\author{
Iyoh Mastiyah \\ Puslitbang Pendidikan Agama dan Keagamaan, Badan Litbang dan Diklat, Kementerian Agama \\ Jl. M.H. Thamrin No. 6 Jakarta Pusat, Daerah Khusus Ibukota Jakarta \\ email: mastiyah9@gmail.com
}

Naskah Diterima: 03 Juli 2018; Direvisi: 28 Agustus 2018; Disetujui: 01 Desember 2018

\begin{abstract}
This article is written based on the research conducted amongst the students of Madrasah Aliyah Negeri 2 (equivalent to Public Senior High School) and Public Senior High School 3 in Bogor. This research was carried out by using quantitative approach, with the parameter on religiosity aspects (knowledge, internalizing, belief, ritual worship behaviour, social behaviour, and attitude to anticipate negative behaviour). The findings showed that the religiosity level of the students in MAN 2 is higher than in SMAN 3. Belief is an aspect that had significant influence in decreasing negative behaviour. Meanwhile, internalizing is a significant aspect to increase religious practice and social behaviour. However, knowledge is an aspect that does not directly influence ritual behaviour (worship), social behaviour, and attitude to anticipate negative behaviour. These findings explained the necessity to improve the teaching of religious education, which is more oriented in building religious belief and internalizing, than merely building knowledge.
\end{abstract}

Keywords: Madrasah Aliyah; Senior High School; Student's Religiosity

\begin{abstract}
Abstrak
Tulisan ini merupakan hasil penelitian yang dilakukan terhadap siswa Madrasah Aliyah Negeri 2 dan Sekolah Menengah Atas Negeri 3 di Kota Bogor. Penelitian ini menggunakan pendekatan kuantitatif dengan fokus pengukuran pada dimensi religiusitas (pengetahuan, penghayatan, keyakinan, praktik ritual keagamaan, perilaku sosial dan perilaku menghindari perbuatan negatif). Temuan penelitian menunjukan siswa MAN 2 mempunyai tingkat religiusitas (aspek pengetahuan, keyakinan, penghayatan, dan perilaku ibadah) lebih tinggi dibandingkan SMAN 3. Dimensi keyakinan mempunyai pengaruh signifikan dalam menurunkan perilaku negatif sedangkan dimensi yang signifikan untuk meningkatkan praktik ibadah dan perilaku sosial adalah penghayatan. Sebaliknya dimensi pengetahuan tidak mempengaruhi secara langsung terhadap perilaku ritual (ibadah), perilaku sosial dan perilaku menghindari hal negatif. Temuan ini menunjukan perlunya peningkatan pengajaran pendidikan agama yang lebih berorientasi pada pembentukan keyakinan dan penghayatan keagamaan dibandingkan pembentukan pengetahuan semata.
\end{abstract}

Kata kunci: Religiusitas Siswa, Madrasah Aliyah, Sekolah Menengah Atas 


\section{PENDAHULUAN}

Sekolah atau madrasah sebagai lembaga pendidikan memiliki nilai dan kultur yang mengajarkan nilai-nilai luhur dan berperilaku positif kepada siswa. Mata pelajaran pendidikan agama khususnya pendidikan agama Islam yang diajarkan memberikan pengetahuan kepada siswa akan nilai-nilai ajaran dasar Islam seperti percaya kepada Tuhan, percaya kepada hal yang gaib, praktik sholat, puasa, sedekah, membaca Alqur'an dan zikir adalah ajaran dasar dalam Islam.

Selain itu aturan agama juga memuat perilaku baik terhadap orang tua, guru, teman, lingkungan sekitar. El-menour, ${ }^{1}$ menyebutkan aturan agama tersebut menjadi fungsi dasar dalam Islam, tidak hanya memuat ibadah ritual yang benar akan tetapi juga memuat aturanaturan yang harus dijalankan keseharian.

Kultur pengajaran pendidikan agama tersebut semestinya mencegah siswa akan perilaku negatif seperti perbuatan curang (menyontek) ketika ujian, atau yang lebih ekstrim adalah berkelahi atau tawuran antar sekolah, meminum minuman keras, mengkonsumsi narkoba atau melakukan hubungan seksual dengan lawan jenis diluar pernikahan. Terkait perilaku hubungan seksual diluar nikah, Survei demografik dan Kesehatan Indonesia menyebutkan pada usia 15-24 tahun terdapat $2,5 \%$ pernah melakukan hubungan seksual di luar pernikahan. ${ }^{2}$

Peristiwa atau perilaku negatif siswa seakan mempertanyakan kembali terkait keberhasilan fungsi pengajaran pendidikan agama Islam di sekolah yang seharusnya mampu menumbuhkan tingkat religiusitas siswa yang tinggi. Melalui pengajaran tersebut sudah seharusnya siswa memperoleh pengetahuan, pemahaman keagamaan yang benar sehingga membentuk sikap dan mampu membedakan perilaku positif dan negatif.

${ }^{1}$ El-Menouar, Y,. (2014). The Five Dimensions of Muslim Religiosity. Results of an Empirical Study, Methods, Data, Analyses | Vol. 8(1), 2014, pp. 53-78 DOI: $10.12758 /$ mda.2014.003

${ }^{2}$ Survei Demografi dan Kesehatan Indonesia. (2012). Kesehatan Reproduksi Remaja Badan Kependudukan dan Keluarga Berencana Nasional. Badan Pusat Statistik, Kementerian Kesehatan, Measure DHS ICF International.
Pendidikan agama di sekolah memuat transmisi keilmuan, sikap, dan perilaku yang ada dalam ajaran agama.

Peristiwa perilaku negatif siswa tersebut menarik untuk bahan kajian penelitian dengan mengaitkannya pada tingkat religiusitas siswa. Religiusitas merupakan komitmen beragama yang dapat berpengaruh terhadap sikap, kecenderungan dan perilaku. Amini dkk. ${ }^{3}$ menyebutkan religiusitas sebagai pemahaman dan kepercayaan kepada Tuhan yang satu, nabi, adanya kehidupan setelah kematian dan pengalaman kedekatan akan Tuhan serta komitmen untuk melaksanakan perintahperintah agama.

Tingkat religiusitas siswa merupakan ukuran yang menggambarkan seberapa baik siswa mengetahui, memahami ajaran agama Islam, meyakini, dan menghayati ajaran tersebut sehingga terimplementasi dalam perilaku ibadah ritual dan ibadah sosial. Definisi ini mengacu pada dimensi-dimensi religiusitas dari Stark \& Glock yaitu pengetahuan, penghayatan, keyakinan, praktik ritual keagamaan dan perilaku sosial. ${ }^{4}$

Praktik perilaku sosial yang negatif seperti menyontek, tawuran, melakukan hubungan seksual di luar pernikahan, dan perilaku negatif lainnya dapat dihindari dari sejumlah faktor seperti pengetahuan keagamaan yang baik, penghayatan dan keyakinan agama yang kuat dan praktik ritual keagamaan.

Siswa yang mempunyai tingkat pengetahuan, penghayatan dan keyakinan baik akan nilai-nilai ajaran agama diduga akan mempunyai praktik ritual (ibadah) keagamaan yang baik. Ada keterkaitan antara ibadah ritual (seperti sholat, puasa, dan lainnya) dan praktik keagamaan sosial (seperti menghormati guru, orang tua, teman, dan menghindari perilaku negatif). Ibadah ritual menggambarkan hubungan ketaatan siswa dengan Tuhan yang

${ }^{3}$ Amini, F, et al. (2014). A Study on the Relationship between Religiosity and Forgiveness among Students, Applied Science Reports www.pscipub.com/ASR E-ISSN: 2310-9440 / P-ISSN: 2311-0139.

${ }^{4}$ Stark, R. \& Glock, C. Y. (1968). American Piety: The Nature of Religious Commitment, Berkeley : University of California Press. 
seharusnya mendorong siswa berperilaku sosial baik serta menghindari perilaku negatif. Siswa merasa Tuhan hadir dalam kehidupan sehari-hari.

Penelitian ini dilakukan terhadap siswa MAN 2 dan SMAN 3 di Kota Bogor. Asumsi yang dibangun adalah siswa MA memperoleh frekuensi pengajaran pendidikan agama lebih banyak dibandingkan siswa SMA. Oleh karena itu siswa MA dianggap memiliki tingkat religiusitas tinggi dibandingkan dengan siswa SMA. Penelitian ini diharapkan dapat melengkapi data hasil penelitian terdahulu tentang religiusitas dan menambah kajian ilmiah tentang kondisi religiusitas siswa pada lembaga pendidikan.

Berdasarkan uraian di atas, pertanyaan penelitian yang diajukan yaitu; (a) Sejauhmana tingkat religiusitas (pengetahuan, keyakinan, penghayatan, praktik ritual/ibadah, praktik sosial dan menghindari praktik perilaku negatif) siswa MAN 2 dan siswa SMAN Kota Bogor; (b) Apakah ada perbedaan tingkat religiusitas (pengetahuan, keyakinan, penghayatan, praktik ritual/ibadah, praktik sosial dan menghindari praktik perilaku negatif) siswa MAN 2 dan siswa SMAN 3 Kota Bogor; dan (c) Apakah dimensi religiusitas siswa (pengetahuan, keyakinan, penghayaran) mempengaruhi terhadap perilaku ritual (ibadah), perilaku sosial dan perilaku menghindari perbuatan negatif.

Tujuan penelitian ini untuk mengetahui: (a) tingkat religiusitas (pengetahuan, keyakinan, penghayatan, praktik ritual/ibadah, praktik sosial dan menghindari praktik perilaku negatif) siswa MAN 2 dan siswa SMAN 3 Kota Bogor; (b) Perbedaan tingkat religiusitas (pengetahuan, keyakinan, penghayatan, praktik ritual/ibadah, praktik sosial dan menghindari praktik perilaku negatif) siswa MAN 2 dengan siswa SMAN 3 Kota bogor; dan (c) Pengaruh dimensi religiusitas (pengetahuan, keyakinan dan penghayatan terhadap dimensi perilaku ritual (ibadah), perilaku sosial dan perilaku menghindari perbuatan negatif.

Manfaat penelitian yaitu dapat menjadi bahan untuk pertimbangan bagi pengambil kebijakan dan atau pengelola MAN 2 dan SMAN 3 Kota Bogor, khususnya guru Pendidikan Agama Islam untuk mengembang- kan pengajaran yang meningkatkan tingkat religiusitas siswa dalam mencegah perbuatan negatif.

Hipotesis penelitian yang diajukan adalah: Ada perbedaan signifikan tingkat religiusitas (pengetahuan, keyakinan, penghayatan, praktik ritual (ibadah), perilaku sosial dan perilaku menghindari perbuatan negatif) siswa MAN 2 dan siswa SMAN 3. Ada pengaruh signifikan dimensi religiusitas (pengetahuan, keyakinan, penghayatan) terhadap praktik ibadah, ibadah sosial dan penurunan perilaku negatif siswa.

\section{Kerangka Konseptual}

Dalam PP No. 55 tahun 2007, tujuan pendidikan agama di sekolah adalah untuk berkembangnya kemampuan peserta didik dalam memahami, menghayati, dan mengamalkan nilai-nilai agama yang menyerasikan penguasaannya dalam ilmu pengetahuan, teknologi dan seni. Pendidikan agama mendorong peserta didik untuk taat menjalankan ajaran agamanya dalam kehidupan sehari-hari dan menjadikan agama sebagai landasan etika dan moral dalam kehidupan pribadi, berkeluarga, bermasyarakat, berbangsa, dan bernegara.

Pendidikan agama di madrasah/sekolah terdapat 3 hal pokok yang tercakup dalam pendidikan keimanan yaitu percaya kepada Tuhan yang satu, adanya malaikat, adanya nabi, kitab dan adanya hari akhir. Pendidikan ibadah yaitu praktik ajaran agama dalam kehidupan sehari-hari (Ibadah kepada Tuhannya dan ibadah sosial dengan lingkungan sekitar). Pendidikan akhlak yaitu mengajarkan pembentukan pribadi Islami. Ketiga komponen tersebut akan membentuk karakter siswa yang memiliki sikap dan perilaku religiusitas yang mencegah dari perilaku negatif.

Penelitian terkait religiusitas umumnya dikaitkan dengan sikap atau perilaku positif atau negatif. Penelitian Reza, ${ }^{5}$ ada hubungan positif antara religiusitas dengan moralitas (perilaku sopan santun, hormat pada guru, pergaulan sehat sesama siswa). Hasil penelitian

${ }^{5}$ Reza, I, F. (2013). Hubungan Antara Religiusitas Dengan Moralitas Pada Remaja Di Madrasah Aliyah (MA). Jurnal Humanitas, X(2). 
Aflakseir, ${ }^{6}$ menemukan bahwa ada hubungan positif antara religiusitas dengan kebahagiaan psikologis dan tujuan hidup. Demikian juga penelitian Ismail dan Desmukh, menemukan ada hubungan positif antara religiusitas dengan kebahagiaan psikologis (kebersamaan, tidak cemas, kebahagiaan hidup). Sejalan dengan itu, Hackney dan Sanders ${ }^{7}$, mengungkap hal yang sama bahwa religiusitas adalah faktor penting yang dapat berperan bagi kesehatan mental (depresi, kecemasan, perasaan bersalah, perasaan tidak nyaman atau tidak tenang dan lainnya). Selanjutnya Amir Fakhraei dan Alinaghizadeh, ${ }^{8}$ juga mengungkap ada pengaruh positif antara religiusitas yaitu aspek berdoa dan berpuasa atas kesehatan mental (depresi, social dysfunction). Penelitian Mooney, ${ }^{9}$ menjelaskan keterkaitan hubungan yang signifikan antara religiusitas dengan prestasi belajar dan kepuasan.

Penelitian hubungan religiusitas dengan perilaku negatif seperti Nuandri dan Widayat, ${ }^{10}$ Onyebuchukwu, Sholarin dan Emerenwa, ${ }^{11}$ menyebutkan bahwa ada hubungan negatif tingkat religiusitas dengan perilaku pergaulan bebas/seks pra nikah. Religiusitas menjadi faktor pelindung terjadinya perilaku seks pra nikah. Kemudian penelitian lain mengungkap

${ }^{6}$ Aflakseir, A. (2012). Religiosity, Personal Meaning, and Psychological Well-being: A Study among Muslim Students in England. Pakistan Journal of Social and Clinical Psychology, Vol. 10, No. 1, 27-31

${ }^{7}$ Hackney, H, C,. \& Sanders, S, G. (2003). Religiosity and Mental Health: A Meta-Analysis of Recent Studies. Journal for the Scientific Study of Religion, 42:1, 43-55

${ }^{8}$ Amir Fakhraei, A, \& Alinaghizadeh. (2012). The impact of praying and fasting on the mental health of students attending the Bandar Abbas Branch of Islamic Azad University in Iran in 2012. Life Science Journal, 9(3), http://www.lifesciencesite.com

${ }^{9}$ Mooney, M. (2010). Religion, College Grades, and Satisfaction among Students at Elite Colleges and Universities. Sociology of Religion, 71:2 197-215. doi:10.1093/socrel/srq035

${ }^{10}$ Nuandri, \& Widayat. (2014). Hubungan Antara Sikap terhadap Religiusitas dengan Sikap terhadap Kecenderungan Perilaku Seks Pranikah pada Remaja Akhir yang Sedang Berpacaran di Universitas Airlangga Surabaya, Jurnal Psikologi Keperibadian dan sosial.

${ }^{11}$ Onyebuchukwu, I, J,. Sholarin, M, A \& Emerenwa, A, B. (2015). Age, Gender, Religiousity and Family Factors on Sexual Attitude and Behaviour of University of Ibadan Undergraduate Students, Research on Humanities and Social Sciences, 5(60, h. 2225-0484 ada hubungan negatif antara religiusitas dengan perilaku mengkonsumsi obat. ${ }^{12}$

Penjelasan tersebut menggambarkan bahwa religiusitas mempunyai keterkaitan positif dengan peningkatan sikap dan perilaku positif (prestasi pendidikan, kepuasan diri, kebahagiaan, kejujuran akademik dan lainnya) serta mencegah dari sikap negatif (depresi, kecemasan, perasaan bersalah) atau perilaku negatif (kecurangan akademik, mengonsumsi obat atau pergaulan bebas pra nikah).

Religiusitas adalah teminologi yang sulit untuk didefinisikan. Setiap para ahli mempunyai pendekatan yang berbeda terutama mendefinisikan religiusitas. Menurut Amini $\mathrm{dkk},{ }^{13}$ religiusitas sebagai pemahaman dan kepercayaan kepada Tuhan yang satu, nabi, adanya kehidupan setelah kematian dan pengalaman kedekatan akan Tuhan serta komitmen untuk melaksanakan perintahperintah agama.

Pendefinisian religiusitas bersifat multi dimensi yang menggabungkan aspek kognitif, emosional, motivasi, dan perilaku keagamaan. Oleh karena itu pengukuran variabel ini menurut Hill dan Maltby, ${ }^{14}$ harus mempertimbangkan beberapa aspek yaitu aspek teoritis (kejelasan konseptual dari dimensi yang diukur), aspek psikometri (validitas dan reliabilitas alat ukur), sampel yang mewakili, dan kepekaan instrumen untuk mengukur konsep religiusitas.

Stark dan Glock, mengemukakan bahwa religiusitas merupakan seberapa jauh pengetahuan, tingkat keyakinan akan ajaran agama, penghayatan terhadap nilai-nilai agama yang terinternalisasi dalam ketekunan pelaksanaan ajaran agama (beribadah. Ada 5 (lima) dimensi religiusitas menurut Stark dan Glock, yaitu, knowledge aspect (dimensi

${ }^{12}$ Ghuman, \& Hoque. (2015). Effect Of Religious Beliefs On Substance Use Among South African High School Students. Southeast Asian J Trop Med Public Health, 46(2).

${ }^{13}$ Amini, F, et al, Loc-cit

${ }^{14}$ Hill, P. C. \& Maltby, L. E,. (2009). Measuring religiousness and spirituality: Issues, existing measures, and the implications for education and well-being, In M. de Souza et al. (Eds.), International handbook of education for spirituality, care and wellbeing (pp. 3350). New York: Springer. 
pengetahuan), belief aspect (keyakinan), feeling aspect (penghayatan), practice aspect (praktik keagamaan), effect aspect (dimensi pengaruh). ${ }^{15}$

Dimensi pengetahuan keagamaan adalah dimensi yang menerangkan seberapa jauh seseorang mengetahui tentang ajaran agamanya terutama yang ada di dalam kitab suci. Sementara menurut El-Menouar, konten Alqur'an dan sunah nabi merupakan sumber utama pengetahuan ajaran Islam dan diharapkan setiap muslim mengetahui ajaranajaran dasar yang tertuang di dalamnya.

Dimensi keyakinan adalah sejauhmana seseorang menerima hal-hal yang dogmatik di dalam ajaran agamanya. Demikian juga Beshlideh, Allipour dan Yailagh, ${ }^{16}$ menyebutkan kepercayaan kepada Tuhan dan kepercayaan adanya kehidupan setelah kematian termasuk dalam dimensi kepercayaan (keyakinan). Sedangkan Amini dkk, menyetarakan dengan dimensi ideologi. Kepercayaan akan ajaran agama yang diikuti oleh pemeluk agama. Unsur kepercayaan yaitu adanya surga dan neraka serta adanya keadilan dalam setiap perbuatan baik dan buruk juga masuk dalam dimensi ini.

Dimensi penghayatan terdiri dari perasaan dan pengalaman-pengalaman keagamaan yang pernah dirasakan dan dialami. El-Menoaur menyebutkan indikator ini seperti merasa kehadiran adanya Tuhan, adanya hukuman dan hadiah dari Tuhan. Dimensi ini menekankan aspek persepsi komunikasi dengan sesuatu yang bersifat supranatural. Sedangkan Beshlideh, Allipour dan Yailagh, menyatakan sebagai perasaan beragama.

Pengharapan terkabulnya doa adalah penghayatan pemeluk agama akan ajaran agama dengan menghubungkannya pada yang supranatural. Menurut Amirfakhraei dan Alinaghizadeh, ${ }^{17}$ berdoa adalah aktifitas spiritual yang menciptakan hubungan dengan

\footnotetext{
${ }^{15}$ Stark, R. \& Glock, C. Y, Op-cit

${ }^{16}$ Beshlideh, K, Allipour, S., \& Yailagh, M, S, (2009). The Causal Relationship between Religious Beliefs and Mental Health, with Mediating Role of SelfEsteem in University Students. Journal of Education \& Psychology, 3(2), pp. 25-38 Loc-cit
}

entitas yang lebih tinggi (Tuhan). Ini adalah aktifitas dasar dalam setiap agama termasuk Islam, Kristen, Yahudi, Budha. Berdoa dapat memperkuat rasa pengendalian dan menstimulus kekuatan internal seseorang.

Adapun dimensi praktik keagamaan atau ibadah yaitu mengerjakan kewajiban ritual dalam agamanya. Unsur yang ada dalam dimensi ini mencakup pemujaan, kultur dan komitmen seseorang dalam agamanya. Dimensi ini berkaitan erat dengan perilaku keagamaan yang berarti segala tindakan perbuatan atau ucapan yang dilakukan seseorang (perilaku) yang dilakukan karena adanya pengetahuan keagamaan, kepercayaan kepada Tuhan dengan ajaran, kebaktian dan kewajiban yang bertalian dengan kepercayaan. Menurut El-Menoaur, ${ }^{18}$ dimensi ini adalah praktik keagamaan atau ritual yang tertera dalam rukun Islam seperti melaksanakan sholat, puasa, zakat, ibadah haji. Amini dkk. menyebutkan bahwa partisipasi dalam acara keagamaan serta membaca Alqur'an termasuk ke dalam dimensi ini.

Dimensi konsekuensi yaitu dimensi yang mengukur sejauh mana perilaku seseorang konsekuen dengan ajaran agamanya dalam kehidupan sosial bermasyarakat. Dimensi ini berkaitan dengan perintah dan larangan yang ada dalam ajaran Islam. Menurut El-menouar, aturan agama adalah fungsi penting yang menjadi pedoman dalam beribadah yang benar, juga aturan-aturan keseharian. Ajaran agama memerintahkan untuk menjauhi minuman alkohol, perbuatan curang dan menghindari berhubungan seksual dengan lawan jenis. Menurut Inglish, ${ }^{19}$ dimensi ini berkaitan dengan moral individu dan perilaku sosial.

Menurut Salleh, ${ }^{20}$ ada lima dimensi pengukuran yang mengukur religiusitas berdasarkan model Stark dan Glock. Model ini tidak diragukan lagi dan dapat digunakan sebagai pendekatan yang dapat menjelaskan

${ }^{18}$ El-Menouar, Y,. (2014). Loc-cit

${ }^{19}$ Inglish, T, F,. (1980). Dimensions of Irish Students' Religiosity. The Economic and Social Review, 11(4), pp. 237-256.

${ }^{20}$ Salleh, M, S,. (2012). Religiosity in Development: A Theoretical Construct of an IslamicBased Development. International Journal of Humanities and Social Science, 2(14). 
religiusitas Islam. Meskipun demikian dalam menurunkan menjadi komponen dan indikator yang mengukur dimensi tersebut perlu berbeda karena pada dasarnya dibangun atas dasar kepercayaan pada agama Kristen. Sedangkan dimensi religiusitas menurut Islam tidak dapat dilepaskan dari rukun Iman, rukun Islam, ibadah dan akhlak.

Kraus dkk. ${ }^{21}$ menjelaskan pengukuran religiusitas menurut Islam mengacu pada Muslim Religiosity Personality Inventory (MRPI). Model religiusitas dalam perspektif Islam dapat diturunkan dalam dua konstrak yaitu pertama dokrin ketuhanan bahwa Tuhan itu satu. Ini adalah pondasi dasar seorang muslim yang disebut akidah Islam yaitu representasi dari rukun iman. Konstrak kedua disebut religious personality yang menggambarkan ibadah yaitu hubungan manusia dengan Tuhan (hablum minallah) ataupun hubungan antara muslim dengan lainnya (hablum minannas). Kedua hal tersebut adalah refleksi dari rukun Islam yang menghasilkan perbuatan baik yang disebut amalan sholeh.

\section{Model dan Instrumen Pengukuran Variabel}

Model yang dibangun dalam penelitian ini menggunakan pendekatan Stark dan Glock, yaitu dimensi pengetahuan, keyakinan, penghayatan, praktik ritual, perilaku menghindari perbuatan negatif dan perilaku sosial. Instrumen penelitian dieksplorasi untuk mewakili pengukuran dimensi religiusitas tersebut. Penggunakan teori Stark dan Glock dalam penelitian ini sangat relevan untuk mengukur tingkat religiusitas siswa MA dan SMA dalam konteks religiusitas (Islam). Mengingat teori Stark dan Glock sama-sama untuk mengukur masalah ritual, sikap keagamaan dan perilaku keagamaan.

Dimensi-dimensi yang diukur adalah pengetahuan oleh seberapa jauh siswa mengetahui terhadap ajaran agama baik perintah maupun larangan seperti percaya kepada selain Allah, perintah sholat, puasa, sedekah/zakat, menghormati orang tua, guru

${ }^{21}$ Krauss, et al,. (2005). The Muslim ReligiosityPersonality Inventory (MRPI): Towards Understanding Differences in the Islamic Religiosity among the Malaysian Youth, Pertanika. Journal Social Science \& Human, 13(2): 173-186. dan teman, perintah membaca Alqur'an, berdoa, serta bentuk larangan dalam ajaran Islam seperti larangan meminum khamerl minuman keras dan hukuman berzina.

Dimensi keyakinan diukur sejauh mana siswa merasa adanya pengawasan atau kehadiran Allah dan malaikat dalam keseharian, adanya balasan atas perbuatan baik dan buruk, kepercayaan akan adanya surga dan neraka, kepercayaan kepada semua peristiwa ketentuan dari Allah, keyakinan akan pengabulan do'a serta kepercayaan Alqur'an dan Sunnah sebagai pedoman hidup.

Dimensi penghayatan diukur oleh perasaan sedih/menyesal bila melalaikan kewajiban sholat dan puasa, merasa tidak tenang bila berbuat kasar terhadap orang tua, teman, guru, perasaan hati tentram ketika berdo'a, berziarah serta perasaan sedih melihat teman melakukan perbuatan buruk.

Adapun dimensi praktik ritual (ibadah) diukur oleh seberapa sering siswa melakukan sholat wajib, sunah (dhuha), puasa ramadhan, dan membaca Alqur'an. Sementara dimensi perilaku sosial diukur oleh sejauh mana siswa berbuat baik terhadap guru, orang tua, dan teman serta perilaku bersedekah/zakat.

Dimensi perilaku negatif yaitu seberapa sering siswa terlibat tawuran/berantem, meminum minuman keras atau obat terlarang, makan dikantin tidak membayar, berjudi/ taruhan dengan uang, mencium lawan jenis, berhubungan seksual dengan lawan jenis, terlambat masuk sekolah, tidak membayar ongkos saat naik kendaraan umum dengan sengaja serta perilaku merokok.

Model penelitian ini mengacu pada dimensi religiusitas (Stark \& Glock, 1968) yang tersaji pada Gambar 1.

\section{METODOLOGI PENELITIAN}

Metode yang digunakan dalam penelitian ini adalah kuantitatif dengan jumlah sampel 261 orang, terdiri dari 139 siswa SMAN 3 Kota Bogor dan 122 siswa MAN 2 Kota Bogor. Data diambil melalui kuesioner dengan skala pengukuran likert (1-5). Analisis data diolah dengan metode statistik deskriptif, korelasi, uji perbandingan rerata dengan $t$ test 
dan pengujian model hubungan antara variabel penelitian dengan Partial Least Square (PLS).

Skor rerata ditentukan rentang 1-5 dimana semakin tinggi rerata skor dimensi religiusitas menunjukan kategori sangat baik. Kriteria kualitatif pengetahuan, keyakinan, penghayatan, perilaku ritual (ibadah) serta

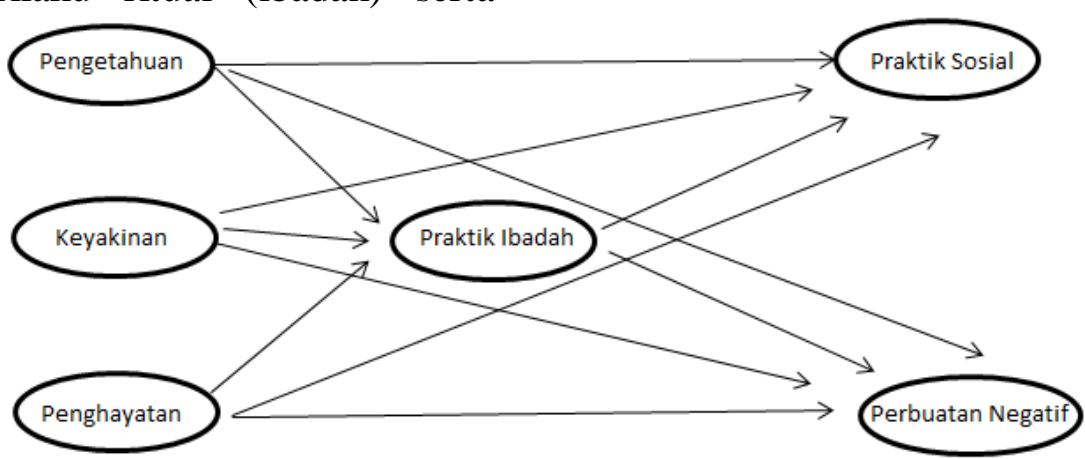

Gambar 1. Model Penelitian perilaku sosial 1,0-1,8 (sangat buruk), 1,9-2,6 (buruk), 2,7-3,4 (cukup), 3,5-4,2 (baik), 4,35,0 (sangat baik). Sedangkan kriteria kualitatif perilaku buruk adalah 1,0-1,8 (sangat baik), 1,9-2,6 (baik), 2,7-3,4 (cukup), 3,5-4,2 (buruk), 4,3-5,0 (sangat buruk).
Adapun analisis PLS digunakan untuk menguji pengaruh antara variabel penelitian. Penggunaan analisis ini karena melibatkan pengukuran variabel yang bersifat laten (tidak dapat diukur secara langsung). Evaluasi analisis PLS terdiri dari evaluasi model pengukuran dan struktural. Ukuran kebaikan evaluasi model pengukuran adalah faktor loading ( $\mathrm{FL} \geq 0,50)$, Composite Reliablity (CR $\geq 0,50$ ), dan Average Variance Extracted (AVE $\geq 0,50$ ). Evaluasi model struktural dilakukan dengan statistik $\mathrm{t}$ ( $\mathrm{t}$ statistik $>1,96$ menunjukan ada pengaruh signifikan) $)^{22}, \quad \mathrm{R}$ square dan Goodness of Fit (GoF).

\section{HASIL DAN PEMBAHASAN}

Demografik responden terdiri dari jenis kelamin siswa, latar belakang pendidikan orang tua, pekerjaan orang tua, frekuensi orang tua menghadiri pengajian (majlis taklim) dan frekuensi mencari informasi keagamaan di internet serta sumber informasi keagaman siswa. Jenis kelamin responden didominasi oleh siswa perempuan 161 orang $(61,7 \%)$, lakilaki 100 orang $(38,3 \%)$. Latar belakang pendidikan orang tua (ayah) didominasi pendidikan sarjana (S1) 109 orang $(41,8 \%)$, pasca sarjana 60 orang (23\%), berpendidikan SMA/SMK/MA 67 orang $(25,7 \%)$ dan 20

${ }^{22}$ Yamin, S.(2016). Tutorial Lengkap 1000 Halaman dengan Software Smart PLS. Jakarta : Titian Pena. orang $(7,6 \%)$ berpendidikan SD/MI dan SMP/MTs, dan sisanya ada 13 orang (5\%) yang tidak menjawab.

Latar belakang pendidikan orang tua (ibu) didominasi oleh mereka pendidikan sarjana (S1) 102 orang $(39,1 \%)$, berpendidikan SMA/SMK/MA 83 orang $(31,8 \%)$, berpendidikan pascasarjana (S2/S3) $35(13,4 \%)$, sisanya berpendidikan SD, SMP atau tidak sekolah. Pekerjaan orang tua (ayah) didominasi pegawai/karyawan swasta mencapai $41,4 \%$. Selain tersebut yaitu mereka yang berstatus PNS/TNI/POLRI 19,2\%, wirausaha ada 17,2\% dan lainnya (guru, dosen) 16,9\%.

Pekerjaan orang tua (ibu) didominasi oleh ibu rumah tangga mencapai $54,4 \%$ selanjutnya PNS/TNI/POLRI $16,5 \%$ dan pegawai swasta $11,1 \%$. Selain memperoleh pengetahuan keislaman di sekolah, sumber informasi keislaman siswa diperoleh dari orang tua $44,66 \%$, ikut majelis taklim $21,36 \%$ dan sisanya mengikuti kegiatan rohani Islam di sekolah, ikut pesantren atau lainnya (membaca buku, internet atau teman).

Secara keseluruhan dari 261 siswa, rerata pengetahuan keagamaan, tingkat keyakinan dan penghayatan akan ajaran agama sangat tinggi/sangat baik. Rerata pengetahuan siswa 4.786 berada dalam rentang 4,2-5,0 (kualitas sangat baik). Ini artinya siswa mempunyai tingkat pengetahuan sangat baik akan nilainilai dasar rukun iman dan rukun Islam. Siswa 
mengetahui kewajiban mereka sebagai seorang muslim seperti hukum percaya kepada selain Allah, perintah menjalankan sholat, puasa di bulan ramadhan, membaca Alqur'an, keharusan berbakti kepada orang tua, guru dan teman, pentingnya berdoa dan berzikir, serta menjauhi perbuatan yang dilarang seperti minuman khomer, berjudi dan lainnya.

Variabel keyakinan berkaitan dengan tingkat keyakinan siswa akan adanya pengawasan dari Allah, malaikat, keyakinan adanya balasan atas perbuatan baik dan buruk, keyakinan pengabulan atas setiap do'a dan keyakinan terhadap Alqur'an dan hadist merupakan petunjuk hidup. Secara keseluruhan rerata tingkat keyakinan siswa sangat tinggi yaitu 4.707. Siswa yakin akan adanya kehidupan akhirat (surga dan neraka), adanya balasan atas setiap perbuatn baik dan buruk.

Tabel 1. Statistik Deskriptif dan Korelasi antara Variabel

\begin{tabular}{|c|c|c|c|c|c|c|c|c|c|c|c|}
\hline & Rerata & $\begin{array}{c}\text { Std. } \\
\text { Deviasi }\end{array}$ & $\begin{array}{l}\text { Penge } \\
\text { tahuan }\end{array}$ & Keyakinan & $\begin{array}{l}\text { Penghaya } \\
\tan \end{array}$ & $\begin{array}{l}\text { Perilaku } \\
\text { Ibadah }\end{array}$ & $\begin{array}{l}\text { Perilaku } \\
\text { Negatif }\end{array}$ & $\begin{array}{c}\text { Perilaku } \\
\text { Terhadap } \\
\text { Guru }\end{array}$ & $\begin{array}{c}\text { Perilaku } \\
\text { Terhadap } \\
\text { Orang } \\
\text { Tua } \\
\end{array}$ & $\begin{array}{c}\text { Perilaku } \\
\text { Terhadap } \\
\text { Teman }\end{array}$ & $\begin{array}{l}\text { Perilaku } \\
\text { Sedekah }\end{array}$ \\
\hline Pengetahuan & 4.786 & 0.301 & 1 & & & & & & & & \\
\hline Keyakinan & 4.707 & 0.366 & $0.563 * * *$ & 1 & & & & & & & \\
\hline Penghayatan & 4.434 & 0.472 & $0.495 * * *$ & $0.615 * * *$ & 1 & & & & & & \\
\hline $\begin{array}{l}\text { Perilaku } \\
\text { Ibadah }\end{array}$ & 4.256 & 0.497 & $0.237 * * *$ & $0.280 * * *$ & $0.375 * * *$ & 1 & & & & & \\
\hline $\begin{array}{l}\text { Perilaku } \\
\text { Negatif }\end{array}$ & 1.210 & 0.273 & $-0.140 * *$ & $-0.247 * * *$ & $-0.199 * * *$ & $-0.216^{* * *}$ & 1 & & & & \\
\hline $\begin{array}{l}\text { Perilaku } \\
\text { Terhadap } \\
\text { Guru }\end{array}$ & 4.258 & 0.599 & $0.178 * * *$ & $0.247 * * *$ & $0.354 * * *$ & $0.282 * * *$ & $-0.232 * * *$ & 1 & & & \\
\hline $\begin{array}{l}\text { Perilaku } \\
\text { Terhadap } \\
\text { Orang Tua }\end{array}$ & 3.615 & 0.433 & 0.041 & 0.091 & $0.123 * *$ & $0.124 * *$ & $-0.181 * * *$ & $0.250 * * *$ & 1 & & \\
\hline $\begin{array}{l}\text { Perilaku } \\
\text { Terhadap } \\
\text { Teman }\end{array}$ & 3.104 & 0.710 & $0.206 * * *$ & $0.218 * * *$ & $0.420 * * *$ & $0.264 * * *$ & $-0.190 * * *$ & $0.318 * * *$ & 0.275 & 1 & \\
\hline $\begin{array}{l}\text { Perilaku } \\
\text { Sedekah }\end{array}$ & 3.727 & 0.822 & 0.064 & 0.019 & 0.099 & $0.170 * * *$ & 0.033 & $0.232 * * *$ & $0.170 * * *$ & $0.187 * * *$ & 1 \\
\hline
\end{tabular}

(**) signifikan pada $\alpha=5 \%,(* * *)$, signifikan pada $\alpha=1 \%$

Variabel penghayatan berkaitan dengan sikap siswa dalam merespon perbuatan baik dan buruk berupa rasa bahagia, senang, sedih, atapun perasaan hati. Rerata dari variabel ini adalah 4.434 yang berarti tingkat penghayatan siswa sangat baik seperti penyesalan ketika tidak berpuasa ramadhan, dan melalaikan sholat, rasa sedih melihat teman sekolah melakukan taruhan (judi), perasaan tergugah ingat akan dosa dan kematian ketika berziarah kubur, dan rasa dekat dengan Allah dan hati merasa tentram ketika berdoa.

Variabel ibadah mencerminkan perilaku siswa muslim dalam menjalankan sholat wajib, sholat sunah, puasa, membaca Alqur'an dan memberi sedekah pada orang lain yang membutuhkan. Variabel ini merupakan cerminan dari rukun islam yang terlihat secara fisik baik oleh diri sendiri atau orang lain. Perilaku menjalankan sholat wajib, puasa ramadhan dan membaca Alqur'an merupakan perwujudan pribadi muslim yang baik.

Rerata perilaku ritual (ibadah) adalah 4.256. Ibadah disini diukur dari ibadah individu hubungan antara siswa dengan Tuhan melalui praktik sholat wajib, sholat sunnah, berpuasa dan membaca Alqur'an. Perilaku menjalankan sholat wajib dan puasa ramadhan merupakan cerminan pengetahuan siswa akan kedua kewajiban ibadah tersebut. Cerminan itu adalah indikator rukun islam. Sedangkan praktik sholat sunah (dhuha) merupakan ibadah sunnah. Perilaku membaca Alqur'an merupakan perilaku amalan sholeh untuk membaca sumber-sumber informasi ajaran islam.

Rerata perilaku menghindari perbuatan buruk adalah 1.210 berada dalam rentang 1,01,8 (sangat baik) yang berarti bahwa siswa cenderung tidak melakukan perbuatan yang 
dilarang terutama berhubungan seksual dengan lawan jenis.

Hasil penelitian ini, semua responden menyatakan tidak pernah melakukan hubungan seksual dengan lawan jenis. Faktor lingkungan yang religius menjadi pelindung bagi siswa untuk tidak melakukan perilaku negatif ini.

Perbuatan baik pada guru seperti mengerjakan pekerjaan rumah dan bersalaman dengan guru mempunyai rerata 4.258 (sangat baik). Hal ini berarti bahwa perilaku siswa di sekolah terhadap guru sangat membanggakan. Meskipun demikian pada perilaku terhadap orang tua mempunyai rerata 3.615 (baik). Perilaku baik terhadap teman yaitu mengucapkan salam dan menasehati teman mempunyai rerata 3.104 (cukup) dan rerata perilaku sedekah 3.727 (baik).

Tabel 2. Hasil uji t-Test

\begin{tabular}{|c|c|c|c|c|c|}
\hline Variabel & Sekolah & $\mathrm{N}$ & Rerata & $\begin{array}{c}\text { Std. } \\
\text { Deviasi }\end{array}$ & $\begin{array}{c}\mathrm{t} \\
\text { Statistik }\end{array}$ \\
\hline \multirow[t]{2}{*}{ Pengetahuan } & Madrasah Aliyah & 139 & 4.822 & 0.274 & \multirow{2}{*}{$2.087 * *$} \\
\hline & Sekolah Menegah Umum & 122 & 4.745 & 0.325 & \\
\hline \multirow[t]{2}{*}{ Keyakinan } & Madrasah Aliyah & 139 & 4.761 & 0.326 & \multirow{2}{*}{$2.548 * *$} \\
\hline & Sekolah Menegah Umum & 122 & 4.646 & 0.399 & \\
\hline \multirow[t]{2}{*}{ Penghayatan } & Madrasah Aliyah & 139 & 4.504 & 0.425 & \multirow{2}{*}{$2.577 * *$} \\
\hline & Sekolah Menegah Umum & 122 & 4.355 & 0.510 & \\
\hline \multirow[t]{2}{*}{ Perilaku Ibadah } & Madrasah Aliyah & 139 & 4.318 & 0.475 & \multirow{2}{*}{$2.166^{* *}$} \\
\hline & Sekolah Menegah Umum & 122 & 4.185 & 0.513 & \\
\hline \multirow[t]{2}{*}{ Perilaku Negatif } & Madrasah Aliyah & 139 & 1.201 & 0.294 & \multirow{2}{*}{-0.590} \\
\hline & Sekolah Menegah Umum & 122 & 1.221 & 0.248 & \\
\hline \multirow[t]{2}{*}{ Perilaku Terhadap Guru } & Madrasah Aliyah & 139 & 4.207 & 0.524 & \multirow{2}{*}{-1.462} \\
\hline & Sekolah Menegah Umum & 122 & 4.316 & 0.672 & \\
\hline \multirow{2}{*}{$\begin{array}{l}\text { Perilaku Terhadap } \\
\text { Orang Tua }\end{array}$} & Madrasah Aliyah & 139 & 3.650 & 0.460 & \multirow{2}{*}{1.365} \\
\hline & Sekolah Menegah Umum & 122 & 3.577 & 0.398 & \\
\hline \multirow{2}{*}{$\begin{array}{l}\text { Perilaku Terhadap } \\
\text { Teman }\end{array}$} & Madrasah Aliyah & 139 & 3.287 & 0.693 & \multirow{2}{*}{$4.608 * * *$} \\
\hline & Sekolah Menegah Umum & 122 & 2.896 & 0.674 & \\
\hline \multirow[t]{2}{*}{ Perilaku Sedekah } & Madrasah Aliyah & 139 & 3.590 & 0.788 & \multirow{2}{*}{ - } \\
\hline & Sekolah Menegah Umum & 122 & 3.883 & 0.835 & \\
\hline
\end{tabular}

(**) signifikan pada $\alpha=5 \%,(* * *)$, signifikan pada $\alpha=1 \%$

Koefisien korelasi menggambarkan hubungan antara variabel. Secara keseluruhan sebagian hubungan antara variabel signifikan yang berarti ada keterkaitan antara variabel penelitian. Variabel pengetahuan terlihat mempunyai korelasi yang cukup tinggi dengan tingkat keyakinan dan penghayatan. Sedangkan pengetahuan, tingkat keyakinan dan penghayatan mempunyai korelasi negatif dengan perilaku negatif. Dari ketiga dimensi tersebut tingkat korelasi terkuat ada dalam hubungan negatif keyakinan dengan perilaku negatif. Adanya pengawasan dari Allah, malaikat dan percaya balasan perbuatan baik dan buruk mendorong siswa untuk menghindari perbuatan negatif. Keyakinan siswa akan adanya kehadiran Allah, malaikat, adanya balasan akan perbuatan baik/buruk mempunyai hubungan dengan menurunnya berperilaku negatif.

Secara keseluruhan tingkat religiusitas antara kedua kelompok siswa yaitu siswa MA dan SMA relatif berbeda signifikan. Rerata pengetahuan, keyakinan dan penghayatan siswa MA lebih tinggi dan signifikan dibandingkan dengan siswa SMA. MA dengan kurikulum kombinasi pendidikan umum dan agama, dimana muatan pendidikan agama lebih tinggi dibandingkan SMA sangat wajar jika membentuk tingkat pengetahuan, keyakinan dan penghayatan nilai keislaman siswa MA lebih tinggi.

Bagi siswa SMA, pengetahuan pendidikan agama Islam hanya diperoleh pada 
mata pelajaran Pendidikan Agama Islam (PAI) dengan frekuensi 2 (dua) jam seminggu. Sebaliknya pada MA pengetahuan ajaran agama Islam diperoleh lebih banyak dan mata pelajaran lebih spesifik. Pengetahuan merupakan transmisi ajaran agama. Pengetahuan mempunyai hubungan korelasional terhadap pembentukan keyakinan dan penghayatan. Dengan siswa lebih berinteraksi pada nilainilai keislaman maka akan meningkatkan tingkat pengetahuan, keyakinan dan penghayatan ajaran agama.

Pendidikan Agama Islam yang diajarkan di sekolah merupakan pintu gerbang siswa memperoleh pengetahuan nilai-nilai keislaman selain dari orang tua. Semakin tinggi tingkat pengetahuan agama Islam, maka siswa akan semakin paham mengenai konsep dasar Islam baik rukun iman, rukun islam, akhlak dan muatan nilai-nilai keislaman lainnya. Nilainilai keislaman tersebut akan membentuk pola keyakinan dan penghayatan ajaran agama sehingga akan menjadi pengendali terhadap perilaku dan akhlak siswa, baik di sekolah, di rumah, maupun di masyarakat. Demikian juga pada tataran ibadah yaitu sholat, puasa, membaca Alqur'an, siswa MA mempunyai nilai retata (4.318) lebih tinggi dan signifikan dibandingkan rerata perilaku ibadah siswa SMA (4.185).

Perilaku negatif yaitu berkaitan dengan hal-hal yang dilarang dalam ajaran agama. Perilaku ini mencerminkan berkaitan dengan perilaku moralitas menghindari hal buruk, dimana dalam uji $t$ test di atas terlihat tidak ada perbedaan signifikan. Ini berarti siswa MA dan SMA cenderung memiliki perilaku yang sama untuk menghindari perbuatan yang dilarang ajaran agama. Meskipun tingkat pengetahuan, keyakinan dan penghayatan akan ajaran agama serta perilaku ibadah berbeda antara kedua kelompok akan tetapi perilaku menghindari perbuatan buruk relatif sama antara kedua kelompok.

Perilaku negatif akan mencerminkan kepribadian dan akhlak siswa. Adanya sanksi dari sekolah atau lingkungan sekitar akan menjadi pengendali bagi siswa untuk tidak melakukan perbuatan negatif. Tawuran atau perkelahian pelajar misalnya, ada aturan sekolah bagi siswa yang terlibat dalam aktifitas tersebut akan diberikan sanksi oleh pihak sekolah. Selain itu perbuatan tersebut juga akan memberikan citra tidak baik bagi orang tua siswa.

Perilaku sosial berupa perbuatan baik terhadap guru dan orang tua yang tercermin dari mengerjalan pekerjaan sekolah yang ditugaskan oleh guru dan bersalaman dengan guru, membantu pekerjaan orang tua di rumah dan bersalaman dengan orang tua ketika akan ke sekolah. Hasil analisis $t$ test diatas menunjukan tidak ada perbedaan signifikan antara kedua kelompok siswa. Penghormatan terhadap guru, orang tua merupakan refleksi ketaatan siswa terhadap guru dan orang tua. Guru dan orang tua adalah panutan dan teladan bagi siswa.

Sebaliknya dalam perilaku sosial yaitu perilaku terhadap teman terlihat berbeda signifikan antara kedua kelompok. Secara rerata tingkat perilaku baik terhadap teman untuk siswa MA adalah 3.287 lebih tinggi dibandingkan siswa SMA 2.896. Untuk perilaku sedekah terlihat nilai rerata siswa SMA (3.883) lebih tinggi dan signifikan dibandingkan rerata siswa MA (3.590).

\section{Pengujian Model Penelitian}

Pengujian model penelitian berkaitan untuk mengetahui pengaruh antara variabel penelitian dari model yang dibangun. Ada dugaan bahwa pengetahuan, keyakinan, penghayatan mempunyai pengaruh terhadap perilaku ibadah, perilaku sosial (perbuatan baik terhadap alam, guru, orang tua dan teman) serta perbuatan pengendalian diri menghindari perbuatan yang dilarang ajaran agama. Teknik statistik yang digunakan adalah PLS. Analisis ini akan mengestimasi model secara simultan baik hubungan antara variabel dengan indikator (model pengukuran) dan hubungan antara variabel penelitian (model struktural).

\section{Evaluasi Model Pengukuran}

Langkah awal adalah evaluasi terhadap model pengukuran yaitu pemeriksaan validitas dan reliabilitas model pengukuran. Uji validitas dilihat dari nilai faktor loading (LF). Penelitian ini bersifat eksplorasi dimana indikator atau item pertanyaan dalam kuesioner yang digunakan untuk mengukur dimensi 
religiusitas dikembangkan mewakili dimensi religiusitas yang dikemukakan Stark dan Glock. Tingkat reliabilitas indikator dilihat dari nilai Composite Reliability (CR), dan Average Variance Extracted (AVE).

Tabel 3. Uji Validitas dan Reliabilitas Model Pengukuran

\begin{tabular}{lcccc}
\hline Variable & $\begin{array}{c}\text { Jumlah Indikator } \\
\text { valid }\end{array}$ & $\begin{array}{c}\text { Faktor Loading } \\
\text { (Tingkat validitas) }\end{array}$ & AVE & $\begin{array}{c}\text { Composite } \\
\text { Reliability (CR) }\end{array}$ \\
\hline Pengetahuan & 8 & $0.574-0.739$ & 0.448 & 0.866 \\
\hline Penghayatan & 6 & $0.655-0.749$ & 0.494 & 0.854 \\
\hline Keyakinan & 7 & $0.520-0.749$ & 0.477 & 0.862 \\
\hline Perilaku Ibadah & 4 & $0.553-0.753$ & 0.470 & 0.778 \\
\hline Perilaku Negatif & 5 & $0.573-0.804$ & 0.488 & 0.824 \\
\hline Perilaku Sosial & 5 & $0.526-0.746$ & 0.406 & 0.771 \\
\hline
\end{tabular}

Hasil pemeriksaan menunjukan bahwa variabel pengetahuan ada 8 indikator yang masuk dalam model, sedangkan satu indikator yaitu pengetahuan siswa terkait hukuman pezina dikeluarkan dari model atau kurang valid. Nilai loading faktor pengetahuan siswa terkait zina kurang dari 0,50.

Semua indikator pengukuran pada variabel penghayatan dan keyakinan dinyatakan valid dengan faktor loading di atas 0,50. Demikian halnya dengan indikator pengukuran variabel perilaku ibadah (sholat wajib, sunah dhuha, membaca Alqur'an dan berpuasa Ramadhan), perilaku sosial (mengucapkan salam terhadap guru, orang tua dan teman, mengerjakan tugas guru, membantu orang tua) dan ada satu indikator yang tidak valid yaitu perilaku bersedekah. Hal ini dapat dipahami bahwa siswa masih memperoleh uang untuk memenuhi kebutuhan sehari-hari berasal dari orang tua sehingga sebaran intensitas perilaku sedekah antara siswa cukup heterogen dan tidak valid menggambarkan pengukuran perilaku sosial dibandingkan item lainnya.

Untuk perilaku negatif ada beberapa indikator yang tidak valid yaitu indikator mencium lawan jenis, berhubungan seksual dengan lawan jenis, dan terlambat masuk sekolah serta merokok. Kelima indikator yang dinyatakan valid adalah terkait tawuran/ berantem, meminum minuman keras atau obat terlarang, makan di kantin tidak membayar, berjudi/taruhan dengan uang dan tidak membayar ongkos naik kendaraan umum dengan sengaja.

Secara umum nilai reliabilitas yang ditunjukkan oleh $\mathrm{CR}$ variabel penelitian me- lebihi nilai rule of thumb yang diharapkan (diatas 0,70). Oleh karena itu, indikator yang masuk dalam model reliabel dalam mewakili pengukuran variabel penelitian. Indikator reliabilitas lainnya yaitu ukuran AVE masih belum optimal dengan AVE kurang dari 0,50.

\section{Evaluasi Model Struktural}

Pengujian model struktural berguna untuk menguji pengaruh antara variabel penelitian yang dihipotesiskan. Analisis ini akan menghasilkan pengaruh variabel yang signifikan dalam menjelaskan keragaman data perilaku ibadah, sosial dan perilaku menghindari hal negatif. Secara statistik, nilai t statistik hasil pengujian di atas 1,96 dinyatakan ada pengaruh signifikan pada tingkat $\alpha=5 \%$.

Pengetahuan tidak signifikan terhadap variabel perilaku ibadah dan perilaku negatif dan perilaku sosial. Nilai t statistik pengujian hipotesis kurang dari 1,96 (tidak signifikan). Pengetahuan siswa akan nilai keislaman tidak signifikan dalam mendorong mereka melakukan perilaku ibadah (sholat, puasa, membaca Alqur'an, dan lainnya). Meskipun mereka mengetahui nilai keislaman akan tetapi tidak secara langsung mendorong mereka untuk melakukan ibadah, menurunkan perilaku negatif dan atau mendorong perilaku sosial. Pengetahuan nilai keislaman yang diperoleh baik di sekolah melalui pengajaran guru atau di luar sekolah (majlis taklim, membaca buku, internet atau lainnya) tidak langsung mendorong siswa untuk menghindari perilaku negatif.

Variabel keyakinan terlihat tidak signifikan pada peningkatan ibadah dan 
perilaku sosial akan tetapi varabel ini berpengaruh signifikan terhadap menurunkan perilaku negatif. Intensitas siswa melakukan ibadah dan perilaku sosial tidak dapat dijelaskan oleh tingkat keyakinan (adanya pengawasan). Adanya perasaan pengawasan
Allah, malaikat atau kepercayaan adanya balasan atas perbuatan baik dan buruk tidak secara langsung mendorong siswa untuk meningkatkan intensitas perilaku ibadah dan perilaku sosial (berbuat baik pada guru, orang tua, teman dan alam sekitar).

Tabel 5. Uji Hipotesis Model Struktural

\begin{tabular}{lcccl}
\hline Variable & $\begin{array}{c}\text { Koefisien } \\
\text { Jalur }\end{array}$ & $\begin{array}{c}\text { Standard } \\
\text { Error }\end{array}$ & T Statistik & Keterangan \\
\hline Pengetahuan -> Ibadah & 0.054 & 0.058 & 0.923 & Tidak Signifikan \\
\hline Pengetahuan -> Perilaku Negatif & 0.001 & 0.066 & 0.016 & Tidak Signifikan \\
\hline Pengetahuan -> Sosial & 0.041 & 0.057 & 0.716 & Tidak Signifikan \\
\hline Keyakinan -> Ibadah & 0.082 & 0.071 & 1.152 & Tidak Signifikan \\
\hline Keyakinan -> Perilaku Negatif & -0.218 & 0.096 & $\mathbf{2 . 2 8 1 * * *}$ & Signifikan \\
\hline Keyakinan -> Sosial & -0.037 & 0.052 & 0.711 & Tidak Signifikan \\
\hline Penghayatan -> Ibadah & 0.312 & 0.080 & $\mathbf{3 . 8 8 6 * * *}$ & Signifikan \\
\hline Penghayatan -> Perilaku Negatif & 0.015 & 0.057 & 0.266 & Tidak Signifikan \\
\hline Penghayatan -> Sosial & 0.337 & 0.076 & $\mathbf{4 . 4 1 4 * * *}$ & Signifikan \\
\hline
\end{tabular}

Keterangan : (**) signifikan pada $\alpha=5 \%$, $(* * *)$ signifikan pada $\alpha=1 \%$

Sebaliknya perasaan adanya pengawasan atau rasa takut akan hari akhirat (surga dan neraka) mendorong siswa untuk menghindari perilaku negatif (t statistik 2,281 >1,96). Koefisien jalur tingkat keyakinan terhadap perilaku negatif adalah 0,218 yang berarti semakin siswa yakin akan adanya pengawasan (Allah, malaikat), adanya balasan baik dan buruk serta keyakinan akan hari kemudian maka akan mengurangi siswa untuk melakukan perbuatan negatif atau semakin baik pengendalian diri yang dilakukan.
Variabel penghayatan berkaitan dengan sikap (sedih, menyesal, tenteram dan lainnya) siswa atas pengalaman nilai keislaman yang dirasakan. Hasil di atas menunjukan variabel penghayatan berpengaruh signifikan terhadap peningkatan perilaku ibadah (t statistik 3.886 >1.96). Variabel ini juga berpengaruh signifikan terhadap peningkatan perilaku sosial seperti perilaku hormat terhadap orang tua, guru dan teman (t statistik 4.414). Akan tetapi penghayatan tidak signifikan pada penurunan perilaku negatif (t statistik $0,266<1,96$ ).

Tabel 6. Pengujian Variabel Mediasi

\begin{tabular}{lcccc}
\hline \multicolumn{1}{c}{ Variable } & $\begin{array}{c}\text { Koefisien } \\
\text { Mediasi }\end{array}$ & $\begin{array}{c}\text { Standard } \\
\text { Error }\end{array}$ & $\begin{array}{c}\text { T } \\
\text { Statistik }\end{array}$ & Keterangan \\
\hline Pengetahuan $\rightarrow$ Ibadah $\rightarrow$ Perilaku sosial & 0.010 & 0.015 & 0.659 & Tidak Signifikan \\
\hline $\begin{array}{l}\text { Pengetahuan } \rightarrow \text { Ibadah } \rightarrow \text { Perilaku } \\
\text { Negatif }\end{array}$ & -0.009 & 0.011 & 0.807 & Tidak Signifikan \\
\hline Keyakinan $\rightarrow$ Ibadah $\rightarrow$ Perilaku sosial & 0.015 & 0.015 & 0.983 & Tidak Signifikan \\
\hline Keyakinan $\rightarrow$ Ibadah $\rightarrow$ Perilaku Negatif & -0.014 & 0.014 & 0.970 & Tidak Signifikan \\
\hline Penghayatan $\rightarrow$ Ibadah $\rightarrow$ Perilaku sosial & 0.057 & 0.028 & $2.040^{* *}$ & Signifikan \\
\hline Penghayatan $\rightarrow$ Ibadah $\rightarrow$ Perilaku Negatif & -0.053 & 0.023 & $2.336^{* *}$ & Signifikan \\
\hline
\end{tabular}

Keterangan : (**) signifikan pada $\alpha=5 \%$

(***) signifikan pada $\alpha=1 \%$

Model penelitian yang dibangun menempatkan variabel praktik ibadah sebagai variabel mediasi. Hasil pengujian statistik terlihat variabel ibadah signifikan memediasi pengaruh penghayatan terhadap peningkatan perilaku sosial dan memediasi pengaruh penghayatan terhadap penurunan perilaku negatrif. Siswa yang memiliki penghayatan 
nilai keagamaan yang baik dengan intensitas menjalankan ibadah (sholat, puasa dan membaca Alqur'an) yang baik maka akan semakin tinggi memiliki perilaku sosial yang baik seperti menghormati guru, orang tua dan teman.

Ibadah individual (sholat, puasa dan membaca al-qur'an) pada dasarnya adalah bentuk ketaatan individu pada Tuhan. Siswa yang baik dalam beribadah merupakan bentuk kedisiplinan individu untuk komitmen pada ajaran agama. Siswa yang memiliki komitmen pada agama akan memiliki dampak untuk berperilaku baik dan mencegah perbuatan negatif.

Hasil uji mediasi ini mengungkap 2 hal penting bahwa untuk mengurangi dampak negatif perbuatan buruk (menyontek, berkelahi, mengonsumsi minuman keras, tidak membayar ketika di kantin) melalui peran keyakinan beragama serta peran peningkatan penghayatan keagamaan melalui intensitas ibadah.

Hasil akhir pengujian model PLS ini adalah melihat kecocokan model atau goodness of fit model (GoF). Menurut Yamin, ${ }^{23}$ adalah nilai R Square dan nilai GoF yaitu akar perkalian antara rata-rata communalities dengan rata-rata $R$ square model. Nilai $R$ square untuk ibadah adalah 0,162 yang berarti pengaruh pengetahuan, keyakinan dan penghayatan terhadap perilaku ibadah adalah $16,2 \%$. Pengaruh pengetahuan, keyakinan dan penghayatan serta perilaku ibadah terhadap perilaku negatif adalah 9,4\% sedangkan pengaruh pengetahuan, keyakinan dan penghayatan serta ibadah terhadap perilaku sosial adalah $19,5 \%$. Nilai GoF adalah 0,264 yang menggambarkan tingkat kecocokan keseluruhan model. Hasil di atas menunjukan bahwa pengujian keterkaitan hubungan antara dimensi religiusitas dapat diterima.

\section{Pembahasan}

Konsep pengukuran dimensi religiusitas dalam penelitian ini mengacu pada model Stark dan Glock, yaitu pengetahuan, ke-

${ }^{23}$ Sofyan Yamin. (2016). Tutorial Lengkap 1000 Halaman dengan SPSS, Lisrel, Smart PLS, Stata dan Eviews. Jakarta: Titian Pena yakinan, penghayatan, perilaku ritual (ibadah), perilaku sosial dan perilaku menghindari hal negatif. Secara keseluruhan rerata pengetahuan, tingkat keyakinan dan penghayatan siswa yang menjadi sampel penelitian sangat tinggi yaitu di atas 4,2 (dalam skala 5). Demikian juga dengan perilaku ibadah hubungan siswa dengan Tuhan.

Menurut Thouless, dalam Afiatin, ${ }^{24}$ ada 4 (empat) faktor yang dapat mempengaruhi religiusitas remaja yaitu : pertama, pengaruh pendidikan dan pengajaran (sekolah, keluarga/ orang tua, tradisi sosial, lingkungan sosial). Kedua, berbagai pengalaman yang dialami membentuk sikap keagamaan. Ketiga, kebutuhan yang belum terpenuhi dan keempat, faktor intelektual.

Keempat faktor tersebut membentuk dimensi religiusitas siswa MA lebih tinggi dibandingkan siswa SMA yaitu dimensi pengetahuan, keyakinan dan penghayatan. Siswa MA lebih intensif berinteraksi dengan nilai keislaman (pengetahuan, keyakinan dan penghayatan) dikarenakan lingkungan pendidikan yang bercirikan Islam. Demikian halnya dengan perilaku ibadah sholat wajib, sunnah (dhuha), puasa dan membaca Alqur'an. Meskipun demikian dalam praktik ibadah sosial seperti menghormati guru dan orang tua, dan perilaku negatif ada kecenderungan antara kedua kelompok relatif sama.

Dari model hubungan antara variabel yang diolah dengan model PLS, terlihat bahwa pengetahuan tidak signifikan berpengaruh terhadap perilaku ibadah, perilaku sosial maupun menghindari hal yang negatif. Pengetahuan yang diperoleh dari pengajaran di sekolah atau di luar sekolah belum sepenuhnya secara langsung mendorong siswa untuk berperilaku baik atau berperilaku negatif. Hasil korelasi yang signifikan antara pengetahuan keagamaan dengan keyakinan dan penghayatan memberikan rekomendasi pengajaran yang tidak saja membentuk pengetahuan dari sisi kognitif semata akan tetapi pengajaran yang berorintasi peningkatan penghayatan siswa.

\footnotetext{
${ }^{24}$ Afiatin, T. (1998). Religiusitas Remaja: Studi Tentang Kehidupan Beragama di Daerah Istimewa Yogyakarta. Jurnal Psikologi, 1, 55-64
} 
Siswa pada dasarnya percaya akan adanya Tuhan, percaya adanya perintah sholat, puasa ramadhan, membaca Alqur'an dan berbuat baik pada sesama akan tetapi pengajaran tersebut perlu dikembangkan dengan pengajaran yang mampu menumbuhkan sikap (perasaan) beragama. Siswa merasa adanya kehadiran Tuhan dalam setiap aktifitas.

Keyakinan berpengaruh signifikan terhadap pengendalian perilaku negatif. Keyakinan merupakan kepercayaan siswa adanya pengawasan Allah dan malaikat serta adanya balasan atas perbuatan baik dan buruk. El-Menouar, menyatakan pada dasarnya dimensi keyakinan beragama tidak dapat dilihat dan diamati secara langsung dalam tataran praktis. Berbeda dengan dimensi ibadah sholat atau membaca Alqur'an. Keyakinan dapat dilihat dari perasaan adanya kehadiran Tuhan dalam setiap aktifitas.

Perilaku negatif atau intensi melakukan perilaku negatif dalam model Azjen, dapat dikendalikan oleh control belief atau adanya pengendalian diri. Siswa yang merasa adanya pengawasan atas setiap perilaku negatif maka akan mengontrol diri mereka untuk tidak melakukan perilaku negatif.

Namun demikian adanya pengawasan Allah dan malaikat tidak sepenuhnya mendorong mereka untuk meningkatkan perilaku ibadah (sholat, puasa, membaca Alqur'an dan zikir). Bentuk persembahan siswa kepada Allah dalam ibadah ritual ataupun bentuk perilaku hubungan sosial siswa tidak dipengaruhi oleh adanya perasaan pengawasan Allah atau adanya balasan atas perbuatan tersebut.

Meskipun berbuat baik kepada orang tua dan guru serta teman adalah amalan sholeh berbuah pahala (kebaikan) akan tetapi perilaku sosial tersebut tidak lahir karena adanya pengawasan Allah, Malaikat atau perasaan mendapat hadiah (pahala) dari perbuatan baik tersebut.

Sebaliknya faktor penghayatan keagamaan menjadi pendorong bagi siswa untuk meningkatkan perilaku ibadah dan berperilaku sosial. Penghayatan di sini berarti adanya perasaan menyesal bila meninggalkan hal yang diwajibkan ajaran agama. Perasaan berdosa ketika meninggalkan sholat dan puasa. Perasaan menyesal bila berbuat tidak baik pada orang lain (orang tua, guru dan teman).

Penghayatan keagamaan merupakan refleksi perasaan siswa yang lahir dari dalam jiwa siswa yang mendorong siswa untuk melakukan ibadah dan berbuat baik pada orang lain (berperilaku sosial).

\section{PENUTUP}

Penelitian terkait religiusitas telah banyak dan terus akan dilakukan oleh para peneliti. Tujuannya adalah ingin membuktikan bahwa religiusitas dapat digunakan sebagai faktor yang dapat menjelaskan berbagai hal terutama sikap dan perilaku manusia. Pada studi ini terlihat bahwa dimensi keyakinan dan penghayatan berpengaruh terhadap perilaku ritual (ibadah), perilaku sosial dan perilaku menghindari hal negatif. Namun di lain hal, terbukti bahwa pengetahuan tidak mempengaruhi faktor lainnya.

Untuk itu pengajaran yang berorientasi pada pembentukan pengetahuan semata (kognitif) tanpa mendorong pembentukan keyakinan dan penghayatan nilai-nilai keagamaan kurang mendorong sikap dan perilaku religiusitas siswa. Oleh karena itu metode pengajaran, kurikulum dan silabus harus memasukan kedua unsur tersebut. Karena perilaku negatif yang kini mengkhawatirkan terutama perkelahian pelajar dan pergaulan bebas siswa dapat dikurangi melalui pengajaran pendidikan agama yang berorientasi pada peningkatan keyakinan dan penghayatan.

\section{UCAPAN TERIMA KASIH}

Tulisan ini telah diseminarkan dan mendapat masukan dari berbagai pihak termasuk dari redaksi jurnal. Karena itu, saya sampaikan terima kasih dan penghargaan setinggi-tingginya kepada redaksi, para peneliti, peserta seminar, narasumber (Prof. Dr. Arsekal Salim, M.A) dan khususnya kepada kepala dan guru-guru MAN 2, kepala dan guru-guru agama Islam SMAN 3 Kota Bogor yang telah membantu pengumpulan data (IPD), sehingga diperoleh data sesuai dengan kebutuhan. Semoga Allah membalas dengan 
pahala yang berlipat ganda dan semoga tulisan ini bermanfaat. Aamiin.

\section{DAFTAR PUSTAKA}

Afiatin, T. (1998). Religiusitas Remaja: Studi Tentang Kehidupan Beragama Di Daerah Istimewa Yogyakarta. Jurnal Psikologi, 1, pp. 55-64

Ajzen, I. (1991). The theory of planned behavior. Organizational Behavior and Human Decision Processes, 50(2), pp. 179-211.

Aflakseir, A,. (2012). Religiosity, Personal Meaning, and Psychological Well-being: A Study among Muslim Students in England, Pakistan Journal of Social and Clinical Psychology, 10(1), 27-31.

Amini, F, et al. (2014). A Study on the Relationship between Religiosity and Forgiveness among Students. Applied Science Reports. http://www.pscipub.com/ASR

Amirfakhraei, A., \& Alinaghizadeh. (2012). The impact of praying and fasting on the mental health of students attending the Bandar Abbas Branch of Islamic Azad University in Iran in 2012. Life Science Journal, 9(3), http://www.lifesciencesite. com

Beshlideh, K., Allipour, S., \& Yailagh, M, S. (2009). The Causal Relationship between Religious Beliefs and Mental Health, with Mediating Role of Self-Esteem in University Students. Journal of Education \& Psychology, 3(2), pp. 25-38

El-Menouar, Y,. (2014). The Five Dimensions of Muslim Religiosity. Results of an Empirical Study. Methods, Data, Analyses, 8(1), pp. 53-78 DOI: 10.12758/mda.2014.003

Hackney, H, C,. \& Sanders, S, G. (2003). Religiosity and Mental Health: A MetaAnalysis of Recent Studies. Journal for the Scientific Study of Religion, 42(1), pp. 43-55
Hill, P. C., and Maltby, L. E,. (2009). Measuring religiousness and spirituality: Issues, existing measures, and the implications for education and wellbeing, In M. de Souza et al. (Eds.), International handbook of education for spirituality, care and wellbeing. New York: Springer. pp. 33-50

Lenski, G. (1961). The Religious Factor, A Sociological Study of Religion's Impact on Politics, Economics, and Family Life. Connecticut: Greenwood Press.

Nuandri, V. T., \& Widayat, I. W. (2014). Hubungan Antara Sikap terhadap Religiusitas dengan Sikap terhadap Kecenderungan Perilaku Seks Pranikah pada Remaja Akhir yang Sedang Berpacaran di Universitas Airlangga Surabaya. Jurnal Psikologi Keperibadian dan sosial.

Peraturan Pemerintah Republik Indonesia Nomor 55 Tahun 2007 Tentang Pendidikan Agama Dan Pendidikan Keagamaan.

Reza, I, F. (2013). Hubungan Antara Religiusitas Dengan Moralitas Pada Remaja Di Madrasah Aliyah (MA). Jurnal Humanitas, X(2).

Survei Demografi dan Kesehatan Indonesia. (2012). Kesehatan Reproduksi Remaja Badan Kependudukan dan Keluarga Berencana Nasional. Badan Pusat Statistik, Kementerian Kesehatan, Measure DHS ICF International.

Stark, R., \& Glock, C. Y. (1968). American Piety: The Nature of Religious Commitment, Berkeley: University of California Press.

Yamin, S,. (2016). Tutorial Lengkap 1000 Halaman dengan SPSS, Lisrel, Smart PLS, Stata dan Eviews. Jakarta: Titian Pena. 